Gut, 1961, 2, 60

\title{
The liver in Hodgkin's disease ${ }^{1}$
}

\author{
RUVEN LEVITAN ${ }^{2}$, HENRY D. DIAMOND, AND LLOYD F. CRAVER \\ From the Lymphoma Service, Department of Medicine, Memorial Center for Cancer and Allied \\ Diseases, the Lymphoma Section of the Division of Clinical Chemotherapy, \\ Sloan-Kettering Institute for Cancer Research, and the Department of Medicine, Cornell University \\ Medical College, New York, New York
}

SYNOPSIS This is a survey of the incidence, morphology, and significance of hepatic changes in Hodgkin's disease

Hepatomegaly and abnormal results in liver function tests are frequently encountered in patients during the course of Hodgkin's disease. It is tacitly assumed in many cases that these findings are part of the general disease process. We were impressed, however, by the frequent occurrence of hepatic changes unrelated to the presence of Hodgkin's disease, and by the difficulty in distinguishing Hodgkin's disease involving the liver from other liver disease in these patients. The present study analyses 112 necropsied cases of Hodgkin's disease with clinical or laboratory evidence of liver disease during life, or both, and reviews the literature in an attempt to elucidate this difficult problem.

\section{REVIEW OF THE LITERATURE}

A brief review of the literature cannot possibly include all the papers on this subject; therefore we apologize for any oversights or omissions.

Thomas Hodgkin (1832), in his original paper, described liver involvement incidentally, and Wilks (1865) noted involvement of the liver with Hodgkin's disease in seven of his 13 cases. In a critical analysis of Hodgkin's original cases, Fox accepted the diagnosis of Hodgkin's disease involving the liver in only two cases (Fox, 1936). In succeeding years, many cases of Hodgkin's disease with pathologically proven liver involvement were recorded by different authors (Barié, 1875; Barron, 1926; Beatty, 1954; Brauneck, 1889; Coronini, 1928; Chevallier and Bernard, 1932; Craver, 1957; Fabian, 1911; Foulon, 1932; Hartfall, 1932; Gall, 1956; Jackson and Parker, 1947; Newman and Pushkin, 1951; Klein, 1955;

'This study was financed by a grant from the Lloyd F. Craver Fund of the Memorial Center for Cancer and Allied Diseases, New York City, New York.

${ }^{2}$ Present address: Massachusets Memorial Hospital, Boston, Mass., U.S.A.
Murchison, 1869; Reed, 1902; Rolleston, 1912; Sternberg, 1936; Symmers, 1944; Wilks, 1865). Liver involvement in Hodgkin's disease was discussed in papers by Fabian (1911), Longcope (1903), Ziegler (1911), Chevallier and Bernard (1932), Sternberg (1936), Wallhauser (1933), Jackson and Parker (1947), and others (Ackerman and del Regato, 1954; Baker and Mann, 1939; Burnam, 1926; Goldman, 1940; Hoster, Dratman, Craver, and Rolnick, 1948; Symmers, 1944; Uddströmer, 1934; Terplan and Mittelbach, 1929), and was more specifically dealt with in papers by Coronini (1928) and later by Gruber (1930), Foulon (1932), Abbatucci and Beatty (1953), and Beatty (1954).

Students of the problem describe Hodgkin's disease involving the liver at necropsy in from 10 to $60 \%$ of the cases (Table I) (Ackerman and del Regato, 1954; Jackson and Parker, 1947; Sternberg, 1936; Symmers, 1944; Wallhauser, 1933; Ziegler, 1911). Hepatomegaly was observed clinically in from 2.3 to $60 \%$ of another series of collected cases (Table I) (Baker and Mann, 1939; Burnam, 1926; Goldman, 1940; Murray, 1908; Uddströmer, 1934). Some authors, basing their opinions on necropsy material primarily, claim that hepatic involvement is a late manifestation of Hodgkin's disease (Diamond, 1958a; Pène, du Paquier, and Pène, 1955), while others maintain that silent liver involvement can be demonstrated early in the course of the disease by liver biopsy (Pène, 1952). There is a similar difference of opinion regarding the onset of hepatomegaly, some describing it as a sign of the terminal stage of Hodgkin's disease (Ackerman and del Regato, 1954), others describing hepatomegaly as a presenting sign ('...forme hepatique et forme hepatosplenomegalic de la maladie de Hodgkin') (Pène, 1952; Pène et al., 1955).

Hodgkin's disease limited to the liver has been reported (Goia, 1935; Symmers, 1944), but most 
TABLE I

INCIDENCE OF HEPATIC ENLARGEMENT AND INVOLVEMENT WITH HODGKIN'S DISEASE IN PATIENTS WITH HODGKIN'S DISEASE AS REPORTED IN THE LITERATURE

\begin{tabular}{|c|c|c|c|}
\hline Author & $\begin{array}{l}\text { No. of } \\
\text { Cases }\end{array}$ & $\begin{array}{l}\text { Hepatic } \\
\text { Enlargement } \\
(\%)\end{array}$ & $\begin{array}{l}\text { Liver } \\
\text { Involvement } \\
\text { at Necropsy } \\
(\%)\end{array}$ \\
\hline Ziegler (1911) & 220 & $60 \cdot 0$ & \\
\hline $\begin{array}{l}\text { Burnam }(1926)^{1} \\
\text { Longcope and McAlpin }\end{array}$ & 173 & $2 \cdot 3$ & \\
\hline $\begin{array}{l}\text { (1927) } \\
\text { Terplan and Mittelbach }\end{array}$ & 77 & $50 \cdot 0$ & \\
\hline (1929) & $29^{2}$ & & $10 \cdot 0$ \\
\hline Wallhauser $(1933)^{1}$ & \multicolumn{2}{|c|}{$\begin{array}{l}1447 \text { (collected from the } \\
\text { literature) }\end{array}$} & $50 \cdot 0$ \\
\hline Uddströmer (1934) & 548 & $25 \cdot 9$ & \\
\hline Sternberg (1936) & $52^{2}$ & & $38 \cdot 0$ \\
\hline $\begin{array}{l}\text { Baker and Mann (1939) } \\
\text { Longscope (Baker and }\end{array}$ & 65 & $30 \cdot 0$ & \\
\hline Mann, 1939) & 117 & $47 \cdot 0$ & \\
\hline Goldman (1940) & 212 & $30 \cdot 6$ & \\
\hline Symmers (1944) & $30^{2}$ & & 58.0 \\
\hline Jackson and Parker (1947) & $\begin{array}{l}63^{2}( \\
192(\end{array}$ & $\begin{array}{l}\text { gkin's granuloma) } \\
\text { gkin's sarcoma) }\end{array}$ & $\begin{array}{l}55 \cdot 0 \\
60 \cdot 0\end{array}$ \\
\hline $\begin{array}{l}\text { Abbatucci and Beatty } \\
\text { (1953) } \\
\text { Ackerman and del }\end{array}$ & $82^{2}$ & & 53.0 \\
\hline $\begin{array}{l}\text { Regato }(1954)^{1} \\
\text { Levitan et al. (1961) }\end{array}$ & $\begin{array}{l}112^{2} \\
875^{3}\end{array}$ & $\begin{array}{l}79 \cdot 6 \\
32 \cdot 5\end{array}$ & $\begin{array}{l}50 \cdot 0 \\
66 \cdot 0\end{array}$ \\
\hline $\begin{array}{l}\text { 'Review article } \\
\text { 'Necropsy series }\end{array}$ & & & \\
\hline
\end{tabular}

workers believe that it is almost invariably a part of a generalized process (Craver, 1957; Hoster et al., 1949). Involvement of the liver is generally, but not always, cited as occurring in conjunction with involvement of the spleen (Craver, 1957; Wallhauser, 1933; Ziegler, 1911).

Coronini (1928), Gruber (1930), and Foulon (1932) distinguish the following types of hepatic involvement by Hodgkin's disease; (1) capsular, (2) nodular or granulomatous lesions localized to the portal triad, (3) diffuse, and (4) encroachment upon or invasion of blood vessels. Simonds (1926) first noted Hodgkin's lesions invading the portal vein. According to some investigators, Hodgkin's disease primarily invades the liver within the portal spaces (Schmorl, 1922; Sternberg, 1936), while others claim that it extends along the periportal spaces (Fabian, 1911; Ziegler, 1911) or along the major biliary ducts and portal vein (Chevallier and Bernard, 1932; Sternberg, 1936).

In Hodgkin's granuloma one encounters focal circumscribed lesions or yellow streaks along the course of the portal areas (Jackson and Parker, 1947), and when extensive fibrosis is present the lesions may resemble gummas (Jackson and Parker, 1947). The hepatic parenchyma surrounding the large lesions may become atrophic (Sherlock, 1955; Symmers, 1944) or may be completely destroyed.
In Hodgkin's sarcoma grayish nodules are seen scattered throughout the liver. These lesions are histologically similar to those in the lymph nodes (Jackson and Parker, 1947). The occurrence of pathological changes unrelated to Hodgkin's disease has been appreciated by others (Abbatucci and Beatty, 1953; Beatty, 1954; Brunner, 1925; Chevallier and Bernard, 1932; Ewing, 1940; Foulon, 1932; Hoster, Zanes, and von Haam, 1949; Loeper and Lebret, 1940; Longcope, 1903; Muller and Boles, 1927; Reed, 1902; Wallhauser, 1933). Specifically noted have been tuberculosis, amyloidosis, focal necrosis, fatty degeneration, fibrosis, cirrhosis, viral hepatitis, congestion, and adhesions. Simultaneous invovlement of the liver with Hodgkin's disease and tuberculosis (Loeper and Lebret, 1940; Wallhauser, 1933), fatty degeneration (Longcope, 1903; Muller and Boles, 1927; Reed, 1902) and fibrosis (Longcope, 1903; Reed, 1902; Tschekulajev, 1951) has also been reported.

Routine laboratory liver function tests have usually been of little help in the diagnosis of lymphomatous involvement of the liver (Sherlock, 1955). Bromosulphalein retention and alkaline phosphatase levels may be abnormal (Sherlock, 1955). According to some, however, the serum alkaline phosphatase level is not as helpful in Hodgkin's disease as in detecting involvement of the liver by cancer (Abbatucci and Beatty, 1953; Ariel and Shahon, 1950; Bodansky and Bodansky, 1952; Mendelsohn and Bodansky, 1952; Ross, Iber, and Harvey, 1956). A similar negative opinion has been expressed with regard to the serum glutamic oxalacetictransaminase (SGOT) level which is, however, invaluable in the diagnosis of hepatitis (Wróblewski and LaDue, 1955). Of all the laboratory tests currently in general use, liver biopsy is probably most helpful in establishing the presence of Hodgkin's disease of the liver. But it must be recognized that a negative biopsy does not necessarily exclude the presence of hepatic Hodgkin's disease (Gall, 1956; Lichtman, 1953; Pène, 1952; Pène et al., 1955; Robert, Bréchot, and Ruynat, 1957; Sherlock, 1955).

\section{MATERIAL AND METHODS}

The case records of 875 patients who were seen at the Memorial Center for Cancer and Allied Disease between 1947 and 1957 and in whom a tissue diagnosis of Hodgkin's disease was made or confirmed by members of the Department of Pathology were reviewed. Three hundred patients $(34.3 \%)$ of the above group presented with clinical evidence pointing to liver disease such as hepatomegaly and/ or abnormal liver function tests. ${ }^{1}$ Of this group with ${ }^{1}$ The cases without hepatomegaly were either jaundiced or had an abnormal bromosulphalein test. 
clinical signs of liver disease and histological proof of Hodgkin's disease, 112 cases $(44 \%)$ were necropsied. The present report is concerned with an analysis of the clinical and pathological data of the latter group only. The significance of the data was evaluated by the application of a corrected $\chi_{2}$ test (Yates) (Hill, 1955) and the degree of significance expressed by the $P$ value.

\section{RESULTS}

Of the 112 necropsied cases, $74(66 \%)$ revealed Hodgkin's disease involving the liver and $38(34 \%)$ did not. In the latter group, however, all the livers exhibited some abnormality of major or minor degree.

The weight of the liver varied between 900 and $4,900 \mathrm{~g}$., the medium weight being $2,600 \mathrm{~g}$. There was no significant difference in weight between those livers involved with Hodgkin's disease and those free of Hodgkin's disease.

Of the 74 cases of Hodgkin's disease directly involving the liver, $64(86.5 \%)$ presented with diffuse infiltration, eight $(10.8 \%)$ presented with nodular lesions, and two (2.7\%) exhibited mixed lesions. Both lobes of the liver were involved in most cases. Hodgkin's paragranuloma was not encountered in the liver in any instance. Fifty-six cases were classed histologically as Hodgkin's granuloma of the liver, and of these $46(82.3 \%)$ showed almost exclusive involvement of the portal triads. In two cases the lesions were limited to the liver capsule. All cases with nodular lesions were classified histologically as granuloma, and in no patient was there invasion or involvement of hepatic blood vessels by Hodgkin's granuloma.

Hodgkin's sarcoma was present in $\mathbf{1 8}$ of the $\mathbf{7 4}$ cases $(24.3 \%)$ with Hodgkin's disease directly involving the liver. Of this number, 14 presented diffuse, extensive liver infiltration while the remaining four involved primarily the portal triads. In five instances, the hepatic parenchmya adjacent to the specific lesions showed marked necrosis. The sarcomatous lesions were necrotic in three instances and invasion of blood vessels was found in five. Invasion of the main trunk of the portal vein with thrombosis was encountered in one case. In another patient, marked fibrosis of a sarcomatous lesion adjacent to the portal vein resulted in portal vein thrombosis without invasion. The hepatic vein was occluded by a thrombus (Chiari's syndrome) without invasion in a case with marked constriction of the portal vein secondary to fibrosis; the portal vein was free of thrombus and the liver was small $(900 \mathrm{~g}$.).

Fifty-nine $(79.6 \%)$ of the 74 cases of Hodgkin's disease of the liver also presented additional patho- logical changes (Table II). Biliary tree pathology related to the Hodgkin's disease was found in 24 patients $(34 \%)$ secondary to granulomatous as well as sarcomatous lesions (Table III). Gall bladder

TABLE II

ABNORMALITIES IN LIVER UNRELATED TO HODGKIN'S DISEASE

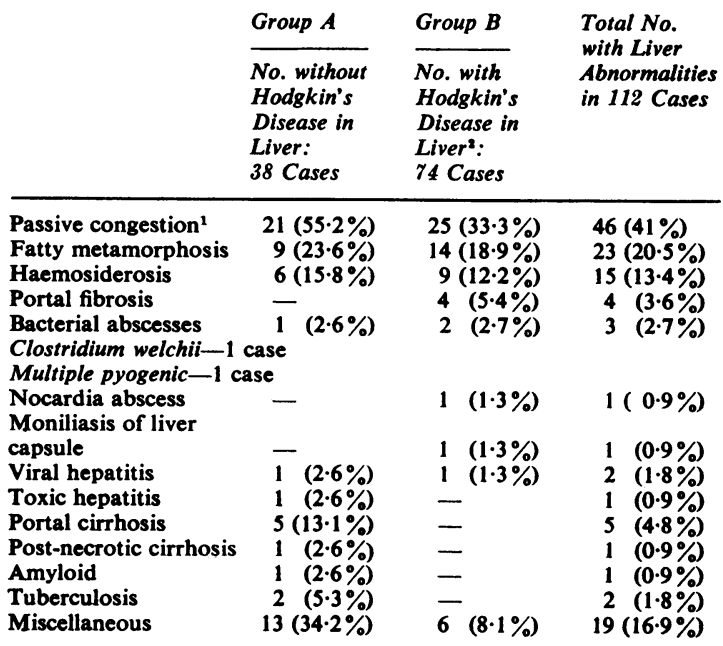

'The incidence in this finding differs between both groups $A$ and $B$ significantly $(P=0.05)$.

'Some patients showed more than one abnormality.

TABLE III

PATHOLOGY DUE TO HODGKIN'S DISEASE IN THE BILIARY SYSTEM

\begin{tabular}{|c|c|c|}
\hline Group $A$ & Group B & Total No. \\
\hline $\begin{array}{l}\text { No. without } \\
\text { Hodgkin's } \\
\text { Disease in } \\
\text { Liver: } \\
38 \text { Cases }\end{array}$ & $\begin{array}{l}\text { No. with } \\
\text { Hodgkin's } \\
\text { Disease in } \\
\text { Liver: } \\
74 \text { Cases }\end{array}$ & $\begin{array}{l}\text { in Biliary } \\
\text { System in } \\
112 \text { Cases }\end{array}$ \\
\hline
\end{tabular}

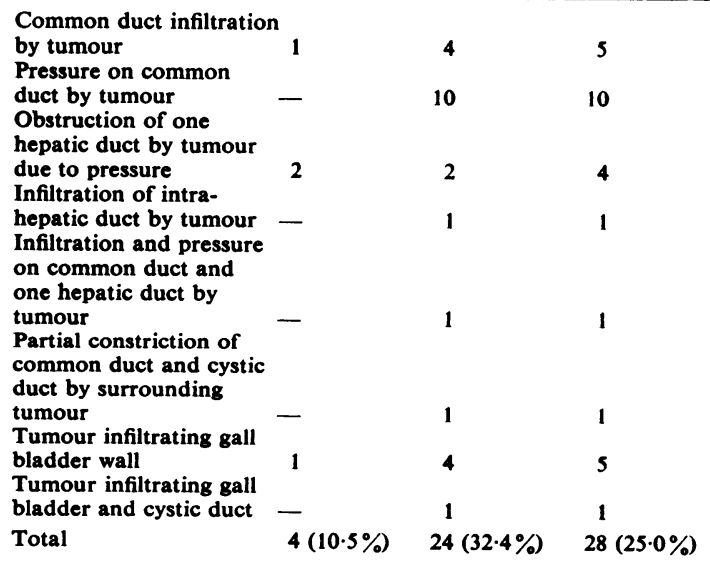

The difference in incidence in biliary tree pathology due to Hodgkin's disease between the two groups is statistically significant $(P=0.05)$. 
TABLE IV

GALL BLADDER PATHOLOGY UNRELATED TO HODGKIN'S DISEASE

\begin{tabular}{|c|c|c|c|}
\hline & Group A & Group B & Total \\
\hline & $\begin{array}{l}\text { No. without } \\
\text { Hodgkin's Disease } \\
\text { in Liver }\end{array}$ & $\begin{array}{l}\text { No. with } \\
\text { Hodgkin's Disease } \\
\text { in Liver }\end{array}$ & \\
\hline Cholelithiasis & $1^{2}$ & $3^{1}$ & 4 \\
\hline Chronic cholecystitis & 1 & 1 & 2 \\
\hline Choledocholithiasis & 1 & - & 1 \\
\hline Total & 3 & 4 & 7 \\
\hline
\end{tabular}

${ }^{1}$ One patient had chronic cholecystitis and cholelithiasis and at the same time Hodgkin's disease of the gall bladder.

${ }^{2}$ This patient also had a mucocele of the gall bladder.

pathology unrelated to Hodgkin's disease was found in only four of the 74 cases $(5.4 \%)$ (Table IV).

Nineteen of the 38 cases in which Hodgkin's disease spared the liver (50\%) exhibited at least one pathological lesion in the liver while the remaining 19 had multiple abnormalities (Table II). Hodgkin's disease limited to the biliary tree, without liver involvement, was seen in only four instances $(10.5 \%)$; this figure was significantly lower than in the group in which the liver itself was also involved.

Associated pathological changes encountered in other organs within the bed of the portal venous system were: (1) Two instances of oesophageal varices in patients with Hodgkin's disease involving the liver parenchyma (detailed report elsewhere, Levitan, Diamond, and Craver, 1959); (2) 30 instances of congestion, infarction, or haemosiderosis of the spleen and one case of amyloidosis of the spleen and pancreas with generalized amyloidosis as well; (3) 15 cases of fibrosis, focal necrosis, or abscesses of the pancreas; (4) four benign gastric ulcers and five duodenal ulcers. The distribution of Hodgkin's lesions in various organs in general is listed in Table $\mathbf{V}$.

\section{TABLE V}

ORGANS AFFECTED BY HODGKIN'S DISEASE AT TIME OF NECROPSY IN 112 CASES $^{1}$

\begin{tabular}{llll} 
Organ & $\begin{array}{l}\text { No. of } \\
\text { Cases }\end{array}$ & Organ & $\begin{array}{l}\text { No. of } \\
\text { Cases }\end{array}$ \\
\hline Spleen & $76(67.8 \%)$ & Breast & $4(3.6 \%)$ \\
Liver & $74(66 \%)$ & Bladder & $4(3.6 \%)$ \\
Lungs & $39(34.8 \%)$ & Uterus & $4(3.6 \%)$ \\
Bone marrow & $33(29.5 \%)$ & Pericardium & $3(2 \cdot 7 \%)$ \\
Gastrointestinal tract & $26(23.2 \%)$ & Ovaries & $3(2 \cdot 7 \%)$ \\
Pancreas & $26(23.2 \%)$ & Fallopian tubes & $2(1.8 \%)$ \\
Kidney & $12(10.7 \%)$ & Ureter & $1(0.9 \%)$ \\
Adrenal & $12(10.7 \%)$ & Vagina & $1(0.9 \%)$ \\
Diaphragm & $9(8.0 \%)$ & Brain (proper) & $1(0.9 \%)$ \\
Thyroid & $6(5.4 \%)$ & Dura & $1(0.9 \%)$ \\
Heart & $4(3.6 \%)$ & Pituitary & $1(0.9 \%)$
\end{tabular}

${ }^{1}$ Most patients had several organs involved.
TABLE VI

MECHANISMS CONTRIBUTORY TO DEATH AS DETERMINED AT NECROPSY

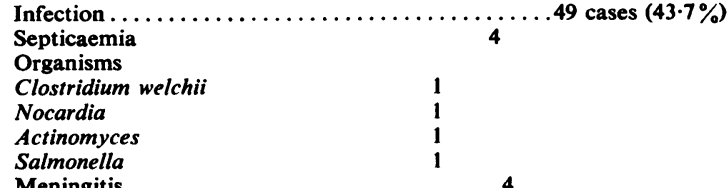

Meningitis

Organisms

Cryptococcus neoformans 2

Pneumococcus Type I

Listeria monocytogenes

Pulmonary pyogenic abscess

Bronchopneumonia

Lobar pneumonia

Tuberculosis

Miliary

Tuberculoma of brain

Tuberculoma of lung

Moniliasis of lung

Pulmonary histoplasmosis

Acute bacterial endocarditis (organism?)

Generalized Hodgkin's disease (with debility,

toxaemia) ...............................27 cases $(24.0 \%)$

Uraemia ...................................... cases $(12.5 \%)$

Compression of both pelves by tumour

Tumour in both kidneys (extensive)

3

Membranous glomerulonephritis

Radiation arteriolitis and acute membranous

glomerulonephritis

Multiple renal cysts and nephrosclerosis

Chronic pyelonephritis and renal infarct

Chronic pyelonephritis, membranous

Glomerulonephritis and multiple calculi

Cholemic nephrosis

Haemorrhage.......................... cases $(10.7 \%)$

Cerebral and/or subarachnoid

Gastrointestinal

Retroperitoneal

Hepatic com

Hepatitis

3

1

1

Perforation of stomach due to Hodgkin's disease 2 cases $(1.8 \%)$

Congestive heart failure.................

Constrictive pericarditis

Verrucous endocarditis

1

Brain tumour (ependymoma of fourth ventricle). . . . case $(0.9 \%)$

Hodgkin's disease of the brain................ case $(0.9 \%)$

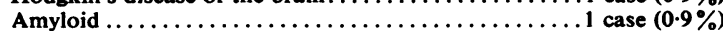

Factors contributing to death in this series are listed in Table VI. It is of interest to note that five patients $(4.5 \%)$ died of causes apparently unrelated to Hodgkin's disease, viz., hepatic coma secondary to hepatitis (two cases), congestive heart failure (two cases), and ependymoma of the fourth ventricle (one case). An important role was attributed to infection in 49 cases $(43.7 \%)$, but was considered the primary cause of death in only $16(14.3 \%)$, the presenting infection being in the form of septicaemia, meningitis, miliary tuberculosis, cerebral tuberculoma, acute endocarditis, lobar pneumonia, or pulmonary abscess. In the remaining patients, infection was considered to be a terminal event. Four patients succumbed to cerebral or subarachnoid haemorrhage, or both, in each case apparently 
secondary to severe thrombocytopenia. In contrast, of seven patients in whom gastrointestinal haemorrhage was a major factor contributing to death, only one showed thrombocytopenia, the source of bleeding in the remaining six being attributable to oesophageal varices (one case), Hodgkin's disease of the stomach (two cases), or duodenal ulcer (three cases). Uraemia was a frequent terminal event (14 cases), and membranous glomerulonephritis was encountered in five of these cases. Gastric perforation secondary to Hodgkin's disease was seen in two cases. Generalized Hodgkin's disease, with debility and 'toxaemia' in the absence of any specific additional cause, was considered the cause of death in 26 cases $(24 \%)$. Only one patient in the present series was considered to have died as a direct consequence of Hodgkin's disease of the liver.

Seventeen cases of other neoplastic growths $(15.2 \%)$ were encountered in the total necropsy series (Table VII).

TABLE VII

TUMOURS UNRELATED TO HODGKIN'S DISEASE IN 112 PATIENTS

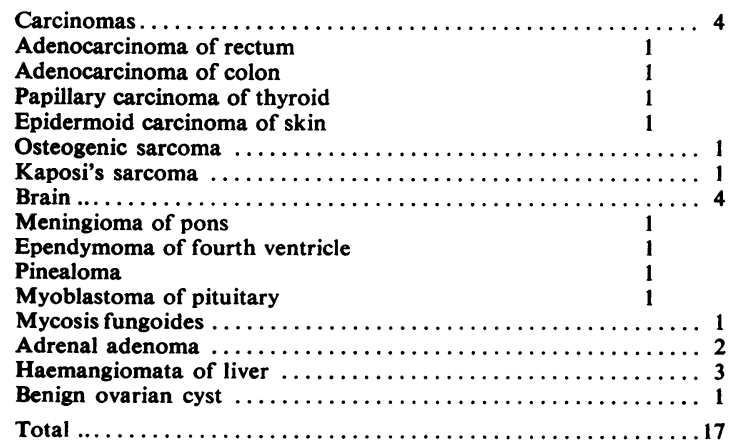

The clinical data in the necropsied group are arrayed, for comparison, into Group A comprising cases with Hodgkin's disease not involving the liver, and Group B cases with Hodgkin's disease involving the liver, and the combined total series.

Sex and age distribution is given in Table VIII. The ratio of males to females in the total series is $1.6: 1$. With one exception all the patients were white. The sex distribution in this series is identical with that reported in whites with Hodgkin's disease dying in 1956 for the entire United States (U.S. Dept. of Health, Education and Welfare, 1958). The youngest patient in our series was aged 15, the oldest aged 78. There was no significant difference in sex distribution between patients with Hodgkin's disease involving the liver and those without such involvement. The clinical diagnosis of histological subtype of Hodgkin's disease, based on tissue biopsy during life, is listed in Table IX. There was no significant difference in distribution of histological types of Hodgkin's disease between Groups A and B. The first clinical evidence of liver disease in relation to the time of diagnosis of Hodgkin's disease was well documented in 74 cases $(66.1 \%)$ of the total series (Table Xa). Over half $(56.2 \%)$ of these developed clinical evidence of liver disease within 24 months of diagnosis of Hodgkin's disease, while $73.8 \%$ developed such evidence within 36 months.

Although liver pathology was often suspected, a clinical diagnosis of a specific type of liver disease was difficult, and a diagnosis of specific liver disease was not overtly expressed in 88 cases $(78.5 \%)$ of the necropsy group. In the remaining cases, Hodgkin's disease involving the liver was diagnosed in $17(18.2 \%)$, viral hepatitis in five $(4.5 \%)$, toxic hepatitis in one $(0.9 \%)$, and passive congestion of

TABLE VIII

AGE $^{1}$ AND SEX $^{2}$ DISTRIBUTION

\begin{tabular}{|c|c|c|c|c|c|c|c|c|c|c|c|c|c|}
\hline \multirow[t]{3}{*}{ Age } & \multicolumn{4}{|c|}{ Group $A$} & \multicolumn{4}{|c|}{ Group B } & \multirow{3}{*}{$\begin{array}{l}\text { Ratio } \\
\text { Group A:B }\end{array}$} & \multicolumn{4}{|c|}{ No. in Total Series of 112 Cases } \\
\hline & \multicolumn{4}{|c|}{$\begin{array}{l}\text { No. without Hodgkin's Disease } \\
\text { in Liver }\end{array}$} & \multicolumn{4}{|c|}{$\begin{array}{l}\text { No. with Hodgkin's Disease } \\
\text { in Liver }\end{array}$} & & \multirow[b]{2}{*}{ Males } & \multirow[b]{2}{*}{ Females } & \multirow[b]{2}{*}{$\begin{array}{l}M / F \\
\text { Ratio }\end{array}$} & \multirow[b]{2}{*}{ Total } \\
\hline & Males & Females & $\begin{array}{l}M / F \\
\text { Ratio }\end{array}$ & Total & Males & Females & $\begin{array}{l}M / F \\
\text { Ratio }\end{array}$ & Total & & & & & \\
\hline $\begin{array}{l}15-19 \\
20-29 \\
30-39 \\
40-49 \\
50-59 \\
60-69 \\
70-79\end{array}$ & $\begin{array}{l}6 \\
4 \\
7 \\
1 \\
1 \\
0 \\
0\end{array}$ & $\begin{array}{l}0 \\
7 \\
7 \\
3 \\
1 \\
1 \\
0\end{array}$ & $\begin{array}{l}x \\
0.57 \\
1.00 \\
0.33 \\
1.0 \\
0.0 \\
0.0\end{array}$ & $\begin{array}{r}6 \\
11 \\
14 \\
4 \\
2 \\
1 \\
0\end{array}$ & $\begin{array}{r}1 \\
6 \\
17 \\
8 \\
10 \\
5 \\
3\end{array}$ & $\begin{array}{l}2 \\
4 \\
7 \\
5 \\
4 \\
2 \\
0\end{array}$ & $\begin{array}{l}0.5 \\
1.5 \\
2.4 \\
1.6 \\
2.5 \\
2.5 \\
3.0\end{array}$ & $\begin{array}{r}3 \\
10 \\
24 \\
13 \\
14 \\
7 \\
3\end{array}$ & $\begin{array}{l}2 \cdot 0 \\
1 \cdot 1 \\
0 \cdot 58 \\
0 \cdot 34 \\
0 \cdot 14 \\
0 \cdot 14 \\
0 \cdot 0\end{array}$ & $\begin{array}{r}7 \\
10 \\
24 \\
9 \\
11 \\
5 \\
3\end{array}$ & $\begin{array}{r}2 \\
11 \\
14 \\
8 \\
5 \\
3 \\
0\end{array}$ & $\begin{array}{l}3.5 \\
0.91 \\
1.7 \\
1.1 \\
2.2 \\
1.7 \\
3.0\end{array}$ & $\begin{array}{r}9 \\
21 \\
38 \\
17 \\
16 \\
8 \\
3\end{array}$ \\
\hline Total & 19 & 19 & $1 \cdot 0$ & 38 & 50 & 24 & $2 \cdot 08$ & 74 & 0.51 & 69 & 43 & 1.6 & 12 \\
\hline
\end{tabular}

${ }^{1}$ The youngest patient in our series was 15 years old.

${ }^{2}$ The sex distribution between Group A and Group B is not statistically significant as determined by the $x^{2}$ (corrected) test. 
TABLE IX

HISTOLOGICAL DIAGNOSIS AS DETERMINED AT BIOPSY ${ }^{1}$

\begin{tabular}{|c|c|c|}
\hline No. in & Group $A$ & Group B \\
\hline $\begin{array}{l}\text { Necropsy } \\
\text { Series of } \\
112 \text { Cases }\end{array}$ & $\begin{array}{l}\text { No. without } \\
\text { Hodgkin's } \\
\text { Disease in Liver } \\
\text { in } 38 \text { Cases }\end{array}$ & $\begin{array}{l}\text { No. with } \\
\text { Hodgkin's } \\
\text { Disease in Liver } \\
\text { in } 74 \text { Cases }\end{array}$ \\
\hline
\end{tabular}

Hodgkin's

granuloma

Hodgkin's

sarcoma

$104(93.0 \%) \quad 36\left(34 \cdot 5^{2}, 94.8 \% \%^{3}\right) \quad 68\left(65.5^{2}, 91 \cdot 9 \%{ }^{4}\right)$

Hodgkin's

$5(4 \cdot 4 \%) \quad 1\left(20^{5}, 2 \cdot 6 \%^{3}\right) \quad 4\left(80 \cdot 0^{3}, 5 \cdot 4 \% \%^{4}\right)$

paragranuloma

$3(2.6 \%)$

$1\left(33 \cdot 3^{6}, 2 \cdot 6 \%^{3}\right)$

$2\left(66 \cdot 7^{6}, 2 \cdot 7 \% \%^{4}\right)$

${ }^{1}$ The biopsies were performed before the onset of liver abnormalities. 'Percentage of 104 cases of Hodgkin's granuloma

${ }^{3}$ Percentage of 38 cases

'Percentage of 74 cases

${ }^{3}$ Percentage of 5 cases of Hodgkin's sarcoma

'Percentage of 3 cases of Hodgkin's paragranuloma

TABLE Xa

DURATION FROM DIAGNOSIS OF HODGKIN'S DISEASE TO CLINICAL EVIDENCE OF LIVER ABNORMALITY IN 74 CASES

\begin{tabular}{lc} 
Time in Months & No. of Cases \\
\hline $1-6$ & $17(23 \cdot 0 \%)$ \\
$7-12$ & $8(10 \cdot 8 \%)$ \\
$13-18$ & $8(10 \cdot 8 \%)$ \\
$19-24$ & $9(12 \cdot 2 \%)$ \\
$25-30$ & $6(8 \cdot 1 \%)$ \\
$31-36$ & $6(8 \cdot 1 \%)$ \\
$37-42$ & $3(4 \cdot 1 \%)$ \\
$43-48$ & $4(5 \cdot 4 \%)$ \\
49 or more & $13(17 \cdot 5 \%)$
\end{tabular}

the liver in one $(0.9 \%)$. Two of the 17 cases diagnosed during life as having Hodgkin's disease of the liver were not so confirmed at necropsy. (Choledocholithiasis, fatty liver, and haemangioma were present in one, and hepatomegaly of undetermined aetiology in the other.) Only two of the five cases diagnosed in life as viral hepatitis gave evidence of viral hepatitis at necropsy, and one of these exhibited Hodgkin's disease in the liver as well. It is possible that the remaining three cases diagnosed as viral hepatitis had healed, without pathological residua, by the time of death.

Liver disease was suspected clinically, before any form of therapy for Hodgkin's disease, in 25 cases $(22.3 \%)$ All other patients in whom liver disease was suspected had received radiotherapy, chemotherapy, or steroids, alone or in combination, before the advent of signs suggestive of liver disease. Seventy-five patients $(67.8 \%)$ received blood transfusions before the onset of liver disease. Six patients $(5.4 \%)$ were known alcoholics, and five of these had portal cirrhosis at necropsy. Clinical symptoms and signs, and laboratory findings in both Groups $\mathrm{A}$ and $B$ are listed in Tables X, XI, and XII. The degree of
TABLE $X$

SYMPTOMS AND SIGNS AT TIME OF ONSET OF LIVER DISEASE

\begin{tabular}{|c|c|c|}
\hline Total & Group A & Group B \\
\hline $\begin{array}{l}\text { Group of } \\
112 \text { Cases }\end{array}$ & $\begin{array}{l}\text { No. without } \\
\text { Hodgkin's } \\
\text { Disease in } \\
\text { Liver in } 38 \\
\text { Cases }^{2}\end{array}$ & $\begin{array}{l}\text { No. with } \\
\text { Hodgkin's } \\
\text { Disease in } \\
\text { Liver in } 74 \\
\text { Cases }^{3}\end{array}$ \\
\hline
\end{tabular}

\begin{tabular}{|c|c|c|c|}
\hline $\begin{array}{l}\text { mia } \\
\text { tomegaly } \\
\text { omegaly } \\
\text { lice } \\
\text { tus } \\
\text { ing manifestations } \\
\text { heral oedema } \\
\text { es } \\
\text { minal pain } \\
\text { stools } \\
\text { pressure } \\
\text { estion } \\
\text { urine } \\
\text { ena } \\
\text { rmal sugar toleranc } \\
\text { atemesis } \\
\text { or hepaticus } \\
\text { r naevi }\end{array}$ & 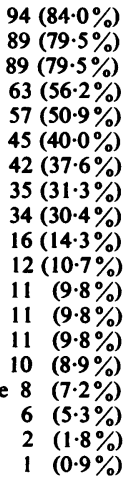 & $\begin{array}{r}19(50.0 \% \\
8(21.1 \% \\
11(28.9 \% \\
7(18.4 \% \\
2(5.3 \% \\
4(10.5 \% \\
5(13.2 \% \\
2(5.3 \% \\
3(7.2 \% \\
2(5.3 \% \\
2(5.3 \% \\
112.6 \% \\
112.6 \%\end{array}$ & $\begin{array}{r}62(84.0 \%) \\
65(88.0 \%) \\
70(94.6 \%) \\
42(56.8 \%) \\
42(56.8 \%) \\
34(46.0 \%) \\
23(32.1 \%) \\
27(36.5 \%) \\
23(31.1 \%) \\
9(12.2 \%) \\
10(13.5 \%) \\
7(9.4 \%) \\
6(8.1 \%) \\
9(12.2 \%) \\
9(9.4 \%) \\
6(8.1 \%) \\
4(5.4 \%) \\
1(1.3 \%) \\
-\end{array}$ \\
\hline
\end{tabular}

'Percentage represents the incidence of signs or symptoms in the whole necropsy group. Many patients had multiple symptoms.

'Percentage represents the incidence of signs or symptoms in the 38 cases which had liver pathology other than Hodgkin's disease. Two patients in this group had extrahepatic obstructive jaundice.

${ }^{3}$ Percentage in this column represents incidence of signs or symptoms in the 74 cases with Hodgkin's disease involving the liver.

The difference of incidence of symptoms between Groups A and B were determined by the $\chi^{2}$ test. The differences, however, were not statistically significant.

\section{TABLE XI}

PERIPHERAL BLOOD

\begin{tabular}{|c|c|c|c|}
\hline & \multirow{2}{*}{$\begin{array}{l}\text { No. in Total } \\
\text { Necropsy } \\
\text { Group of } \\
112 \text { Cases }\end{array}$} & \multirow{2}{*}{$\begin{array}{l}\text { Group A } \\
\text { No. without } \\
\text { Hodgkin's } \\
\text { Disease in } \\
\text { Liver in } 38 \\
\text { Cases }\end{array}$} & \multirow{2}{*}{$\begin{array}{l}\text { Group B } \\
\text { No. with } \\
\text { Hodgkin's } \\
\text { Disease in } \\
\text { Liver in } 7 t \\
\text { Cases }\end{array}$} \\
\hline & & & \\
\hline $\begin{array}{l}\text { Anaemia } \\
\text { Leucocytosis }^{2} \\
\text { Leucopenia }^{3} \\
\text { Thrombocytosis }^{4} \\
\text { Thrombocytopenia }^{5}\end{array}$ & $\begin{array}{l}88(79 \cdot 5 \%) \\
39(34.8 \%) \\
15(13.4 \%) \\
11(9 \cdot 8 \%) \\
26(23.2 \%)\end{array}$ & $\begin{array}{r}24(63 \cdot 1 \%) \\
14(36.8 \%) \\
2(5 \cdot 3 \%) \\
3(7 \cdot 9 \%) \\
10(26 \cdot 3 \%)\end{array}$ & $\begin{array}{l}65(88.0 \%) \\
25(33.8 \%) \\
13(17.6 \%) \\
8(10.8 \%) \\
16(21.6 \%)\end{array}$ \\
\hline
\end{tabular}

${ }^{1}$ Anaemia, less than $11 \mathrm{~g} . \%$ haemoglobin

${ }^{2}$ Leucocytosis, over 10,000 white blood cells per $\mathrm{mm}^{3}$

'Leucopenia, less than 4,000 white blood cells per mm. ${ }^{3}$

'Thrombocytosis, more than $\mathbf{4 0 0 , 0 0 0}$ platelets per $\mathrm{mm}^{3}$

'Thrombocytopenia, less than 90,000 platelets per $\mathrm{mm}$.

clinical hepatomegaly or splenomegaly, or both, and the sex distribution of cases with clinical splenomegaly are listed in Tables XIII, XIV, and XV.

There was no statistically significant difference between Groups A and B with respect to incidence of symptoms and signs, abnormal results in liver function tests, and the presence or degree of clinical 
TABLE XII

LIVER FUNCTION TESTS

\begin{tabular}{|c|c|c|c|c|c|c|}
\hline \multirow[t]{2}{*}{ Test } & \multicolumn{2}{|l|}{ Group $A$} & \multicolumn{2}{|l|}{ Group $B$} & \multirow{2}{*}{$\begin{array}{l}\text { Total No. } \\
\text { Cases Tested }\end{array}$} & \multirow{2}{*}{$\begin{array}{l}\text { Percentage } \\
\text { Abnormal }\end{array}$} \\
\hline & $\begin{array}{l}\text { No. of } \\
\text { Cases Tested }\end{array}$ & $\begin{array}{l}\text { Percentage } \\
\text { Abnormal }\end{array}$ & $\begin{array}{l}\text { No. of } \\
\text { Cases Tested }\end{array}$ & $\begin{array}{l}\text { Percentage } \\
\text { Abnormal }\end{array}$ & & \\
\hline $\begin{array}{l}\text { Bromsulphalein retention } \\
\text { Prothrombin time } \\
\text { Alkaline phosphatase } \\
\text { Total protein } \\
\text { Serum albumin } \\
\text { Serum globulin } \\
\text { Total serum bilirubin } \\
\text { Cephalin flocculation } \\
\text { Thymol turbidity } \\
\text { Total cholesterol } \\
\text { Serum glutamic oxaloacetic transaminase (SGOT) }\end{array}$ & $\begin{array}{r}10 \\
8 \\
26 \\
31 \\
29 \\
22 \\
21 \\
27 \\
24 \\
13 \\
4\end{array}$ & $\begin{array}{r}100 \cdot 0 \\
100 \cdot 0 \\
65 \cdot 4 \\
83 \cdot 9 \\
91 \cdot 0 \\
27 \cdot 3 \\
52 \cdot 4 \\
63 \cdot 0 \\
41 \cdot 7 \\
30 \cdot 8 \\
100 \cdot 0\end{array}$ & $\begin{array}{l}23 \\
23 \\
53 \\
49 \\
48 \\
48 \\
62 \\
61 \\
50 \\
24 \\
20\end{array}$ & $\begin{array}{r}100 \cdot 0 \\
91 \cdot 4 \\
85 \cdot 0 \\
85 \cdot 6 \\
79 \cdot 0 \\
18 \cdot 7 \\
56 \cdot 4 \\
54 \cdot 1 \\
26 \cdot 0 \\
25 \cdot 0^{1} \\
40 \cdot 0\end{array}$ & $\begin{array}{l}33 \\
31 \\
79 \\
80 \\
70 \\
70 \\
83 \\
88 \\
74 \\
37 \\
24\end{array}$ & $\begin{array}{r}100.0 \\
93.5 \\
78.5 \\
85.0 \\
82.9 \\
22.4 \\
55.4 \\
56.8 \\
31.1 \\
27.0 \\
50.0\end{array}$ \\
\hline
\end{tabular}

Abnormal Values

Bromsulphalein test, retention of $8 \%$ or more of injected dye after 45 minutes

Prothrombin time, 16 seconds or more

Alkaline phosphatase, 5 Bodansky units or more

Total protein, below $6.0 \mathrm{~g} . / 100 \mathrm{ml}$.

Serum albumin, below $4.0 \mathrm{~g} . / 100 \mathrm{ml}$.

Serum globulin, below $1.0 \mathrm{~g} . / 100 \mathrm{ml}$. or above $3.0 \mathrm{~g} . / 100 \mathrm{ml}$.

Total serum bilirubin, more than $1.5 \mathrm{mg} . / 100 \mathrm{ml}$.

Cephalin flocculation, $3+$ or more after 48 hours

Thymol turbidity, more than 5.0 units

${ }^{1}$ In two cases the values were below $100 \mathrm{mg} . / 100 \mathrm{ml}$. and in two above $300 \mathrm{mg} . / 100 \mathrm{ml}$. In the latter two cases, obstructive jaundice was present. The differences in incidence of abnormal tests between Groups $\mathbf{A}$ and B were not statistically significant.

TABLE XIII

DEGREE OF CLINICAL HEPATOMEGALY

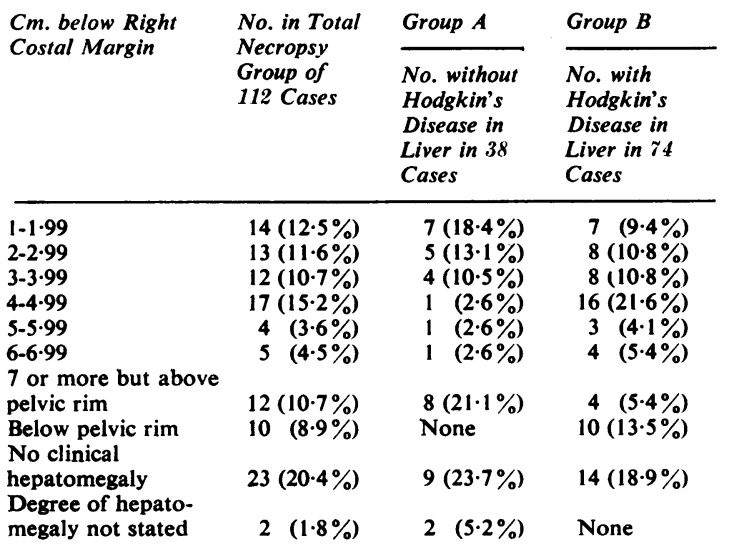

hepatomegaly or splenomegaly. Splenomegaly was found more commonly in males than females in this series $(P=0.01)$. Clinical hepatomegaly was absent in 23 cases $(20.4 \%)$ and splenomegaly was absent in 49 cases $(43.8 \%)$, while 15 cases $(13.4 \%)$ had neither enlarged spleen nor liver and five cases (4.5\%) presented with a palpable spleen but not a palpable liver. There was no good correlation between the size of the liver or spleen estimated by palpation and the size found at necropsy. In no instance were nodules felt clinically in the liver. Scout films of the abdomen were helpful in assessing
TABLE XIV

DEGREE OF SPLENOMEGALY

\begin{tabular}{|c|c|c|c|}
\hline \multirow{2}{*}{$\begin{array}{l}\text { Cm. below Right } \\
\text { Costal Margin }\end{array}$} & \multirow{2}{*}{$\begin{array}{l}\text { No. in Total } \\
\text { Necropsy } \\
\text { Group of } \\
112 \text { Cases }\end{array}$} & \multirow{2}{*}{$\begin{array}{l}\text { Group A } \\
\text { No. without } \\
\text { Hodgkin's } \\
\text { Disease in } \\
\text { Liver in } 38 \\
\text { Cases }\end{array}$} & Group $B$ \\
\hline & & & $\begin{array}{l}\text { No. with } \\
\text { Hodgkin's } \\
\text { Disease in } \\
\text { Liver in } 74 \\
\text { Cases }\end{array}$ \\
\hline $\begin{array}{l}\text { Tip palpable only } \\
1-1.99 \\
2-2.99 \\
3-3.99 \\
4-4.99 \\
5-5.99 \\
6-6.99 \\
7-7.99 \\
8 \text { or more } \\
\text { Below pelvic rim } \\
\text { No clinical } \\
\text { splenomegaly }\end{array}$ & $\begin{aligned} 10 & (8.9 \%) \\
8 & (7.1 \%) \\
7 & (6.2 \%) \\
10 & (8.9 \%) \\
10 & (8.9 \%) \\
5 & (4.5 \%) \\
3 & (2.7 \%) \\
3 & (2.7 \%) \\
4 & (3.6 \%) \\
3 & (2.7 \%) \\
& \\
49 & (43.8 \%)\end{aligned}$ & $\begin{array}{l}5(13.2 \%) \\
\text { None } \\
2(5.3 \%) \\
4(10.5 \%) \\
3(7.9 \%) \\
\text { None } \\
\text { None } \\
\text { None } \\
3(7.9 \%) \\
\text { None }\end{array}$ & $\begin{array}{lc}5 & (6.8 \%) \\
8 & (10.8 \%) \\
5 & (6.8 \%) \\
6 & (8.1 \%) \\
7 & (9.5 \%) \\
5 & (6.8 \%) \\
3 & (4.0 \%) \\
3 & (4.0 \%) \\
1 & (1.4 \%) \\
3 & (4.0 \%) \\
& \\
28 & (37.8 \%)\end{array}$ \\
\hline
\end{tabular}

TABLE XV

RELATION OF CLINICAL SPLENOMEgALY AND SEX

\begin{tabular}{lllc}
$\begin{array}{l}\text { Total Necropsy } \\
\text { Series }\end{array}$ & Males & Females & $\begin{array}{l}\text { Ratio } \\
\text { Males/Females }\end{array}$ \\
\hline $\begin{array}{l}\text { Number of cases } \\
\text { without splenomegaly }\end{array}$ & $24(49.0 \%)$ & $25(51.0 \%)$ & 0.96 \\
$\begin{array}{l}\text { Number of cases with } \\
\text { splenomegaly }\end{array}$ & $45(71.5 \%)$ & $18(28.6 \%)$ & 2.5 \\
Total & $69(61.5 \%)$ & $43(38.4 \%)$ & 1.6
\end{tabular}

The difference in sex distribution between the cases with splenomegaly and the cases without splenomegaly is significant $(P=0.01)$. 
the size of the liver and spleen. Radiological enlargement of the liver was noted in eight cases $(7 \cdot 1 \%)$ in which it was not detected clinically. In like manner, radiological enlargement of the spleen was found in six cases $(5.4 \%)$ without clinically palpable splenomegaly.

Liver biopsy was performed in three cases $(2 \cdot 8 \%)$. The biopsy findings are compared with the final anatomical diagnosis of the liver involvement at necropsy in Table XVI. No mortality or morbidity resulted from the procedure.

\section{TABLE XVI}

COMPARISON BETWEEN LIVER PATHOLOGY AS SEEN ON LIVER BIOPSY SPECIMENS AND AT NECROPSY

\begin{tabular}{ll} 
Findings on Liver Biopsy & Findings at Necropsy \\
\hline $\begin{array}{l}\text { Miliary necrotizing hepatic } \\
\text { granulomatous lesions } \\
\text { ? Tuberculosis }\end{array}$ & $\begin{array}{l}\text { Hodgkin's granuloma of the } \\
\text { liver }\end{array}$ \\
Pericholangiolitic inflammation & $\begin{array}{l}\text { Cholangitic obstruction of } \\
\text { hepatic duct by Hodgkin's disease } \\
\text { Fibrosis }\end{array}$ \\
$\begin{array}{l}\text { Hodgkin's granuloma with } \\
\text { marked fibrosis }\end{array}$
\end{tabular}

The five-year survival from onset of the diagnosis of Hodgkin's disease in the total series (112 cases) was $19.6 \%$ and the 10 -year survival was $4.5 \%$. No difference was noted between Groups A and B.

\section{DISCUSSION}

This retrospective analysis of necropsy material and correlation with clinical data is the only method currently available to assemble complete and detailed information on liver involvement in Hodgkin's disease. Nevertheless, keeping in mind the limitations imposed by the statistical bias of a retrospective study, and the fact that pathological findings at death may not reflect the dynamic changes occurring earlier in the course of the disease, we may acquire an appreciation of the problems encountered in making a precise diagnosis of liver disease, and the nature of the hepatic lesions involved, in patients with Hodgkin's disease.

The several types of Hodgkin's lesions of the liver encountered in this series confirm descriptions by other observers in all important respects (Coronini, 1928; Foulon, 1932; Gruber, 1930; Jackson and Parker, 1947; Simonds, 1926). Diffuse involvement of both lobes of the liver was most common, but the left lobe appeared more extensively involved in cases with associated Hodgkin's disease of the gastrointestinal tract. Nodular lesions were uncommon and, in this series, were seen only with granuloma. Although Hodgkin's sarcoma was found in only $4.4 \%$ of the diagnostic biopsy material, it was found in the liver in $24.3 \%$ of the 74 cases of hepatic Hodgkin's disease and in $21.5 \%$ of the entire necropsy series, illustrating the fact that Hodgkin's granuloma may change to sarcoma during the course of the process. This conversion took place in 19 instances. No significant difference was found between Hodgkin's sarcoma and Hodgkin's granuloma in the frequency of liver involvement.

The involvement of the liver, when present, was much more extensive in the case of Hodgkin's sarcoma than in granuloma and was characterized by massive invasion, blood vessel invasion, and marked atrophy or necrosis in the normal tissue adjacent to the lesions. In the case of Hodgkin's granuloma, on the other hand, diffuse fibrosis of a degree so marked as to obscure the underlying process was encountered.

The frequent occurrence of other liver pathology, particularly passive congestion, fatty metamorphosis, and haemosiderosis, in all cases of Hodgkin's disease with or without direct involvement of the liver by the primary process, is a striking and important finding. Passive congestion occurred less frequently in livers directly involved with Hodgkin's disease $(P=0.05)$, suggesting that it was unrelated to intrahepatic invasion by Hodgkin's disease. No significant difference was found between the several other categories of hepatic abnormality in relation to the presence or absence of direct involvement by Hodgkin's disease. There is no evidence, therefore, to permit any conclusions regarding local factors predisposing the liver to involvement with Hodgkin's disease.

Passive congestion of the liver, which appeared to be a terminal event in a few instances secondary to congestive heart failure or portal hypertension, was not explicable in most instances by such mechanisms.

The presence of fatty metamorphosis of the liver in an unusually high incidence $(20.5 \%)$ suggests the operation of nutritional, metabolic or toxic factors, or all three, as well as anoxia (Popper and Schaffner, 1957). All four of these mechanisms are readily demonstrated or deduced to be present in patients with advanced Hodgkin's disease. The presence of pathological changes in the pancreas in $36.6 \%$ of the cases (Hodgkin's disease $\mathbf{2 3 . 2 \%}$, other diseases $13.4 \%$ ) may have contributed to the development of fatty liver as well (Woldman, Fishman, and Segal, 1959).

All patients with haemosiderosis of the liver $(13.4 \%)$ presented with anaemia, with or without haemolysis, and had received numerous blood transfusions during life. They probably represented, therefore, secondary haemosiderosis. 
In the present series, hepatic involvement with Hodgkin's disease appeared to be part of the generalized process, as has been previously maintained (Craver, 1957; Hoster et al., 1948), and in no instance was Hodgkin's disease limited to the liver alone, as reported in a few cases (Goia, 1935; Symmers, 1944). Extrahepatic biliary pathology due to Hodgkin's disease was more frequent in cases with associated liver involvement $(P=0.05)$, suggesting that the portal areas provide a preferred channel for direct dissemination of the process.

The spleen was involved by Hodgkin's disease in $78.4 \%$ of the cases with hepatic Hodgkin's disease. Other pathological changes were encountered in the spleen in $18.9 \%$, and normal spleens were observed in only $2.7 \%$ of patients with liver involvement. This series confirms the conclusion that '...seldom can the liver be involved and the spleen not' (Ziegler, 1911).

Occlusion of the portal or hepatic vein by associated thrombosis, direct tumour compression or blood vessel invasion $(7.2 \%$ of this series) must be considered in the differential diagnosis of the onset of ascites, jaundice, or liver enlargement in patients with hepatic involvement with Hodgkin's disease.

The incidence of liver involvement by Hodgkin's disease is somewhat higher $(80 \%)$ in the necropsy series than reported by others (Table I), an expected finding in view of the method of selection of the material.

The sex distribution of patients with Hodgkin's disease of the liver did not differ significantly from the cases without liver involvement or from the expected sex distribution in Hodgkin's disease at large (Diamond, 1958c; Gall and Mallory, 1942; U.S. Department of Health, Education and Welfare, 1958; Wallhauser, 1933). This is in contrast to the report of Abbatucci and Beatty (1953) that males more frequently exhibited hepatic involvement than could be anticipated on the sex distribution of Hodgkin's disease in general. A critical analysis of the data on which their conclusion was based (31 males and 13 females with liver involvement and 29 males and 19 females without liver involvement in a total series of 82 cases) by the corrected $x^{2}$ test (Yates) (Hill, 1955) reveals no significant difference from the sex distribution of a number of series of cases of generalized Hodgkin's disease (Diamond, 1958b; Gall, 1956; U.S. Dept. of Health, Education and Welfare, 1958; Wallhauser, 1933). There is no basis, therefore, for assuming a hormonal influence on the frequency of hepatic involvement with Hodgkin's disease.

Massive hepatomegaly, with the liver edge below the pelvic brim, was seen in $8.9 \%$ of the necropsy series, an exception to the statement that marked hepatomegaly is uncommon or rare in Hodgkin's disease (Chevallier and Bernard, 1932; Ziegler, 1911). In all cases with massive hepatic enlargement, Hodgkin's disease was found in the liver at necropsy. Sixty-eight per cent of our series exhibited lesser degrees of hepatomegaly, however, and within this group only $52 \%$ had Hodgkin's disease involving the liver directly. However, in those cases without clinical evidence of hepatomegaly $(20.4 \%)$ of the necropsy series), Hodgkin's disease was found in $60.8 \%$. It would appear, therefore, that with the exception of massive hepatomegaly, there is no good correlation between hepatic enlargement and the presence of Hodgkin's disease in the liver. This may be due, in part, to the lack of correlation between clinical hepatomegaly in life and hepatic weight at necropsy, an observation made with respect to other disease as well and considered to be due to differences in blood content of the organ in life and after death (Schiff, 1957).

Although it is stated that massive hepatomegaly in Hodgkin's disease is almost always associated with massive splenomegaly (Chevallier and Bernard, 1932; Craver, 1957), no good correlation was noted in the present series between the degree of hepatomegaly and the presence or degree of associated splenomegaly. Indeed, splenomegaly was absent in $30.4 \%$ of the cases with hepatomegaly in this series. As with the liver, there was no good correlation between the clinical estimate of splenomegaly and the size of the spleen at necropsy, or between the size of the spleen and the presence of Hodgkin's disease within the spleen.

Splenomegaly was encountered more frequently in males than females both in the necropsy series $(P=0.01)$ and in a larger series of 300 cases of Hodgkin's disease with clinical evidence of liver disease. Such an observation has not been previously recorded but its significance is obscure.

It is clear from this series that hepatomegaly can occur early in the course of Hodgkin's disease and is not limited to the terminal stages as claimed by some (Ackerman and del Regato, 1954). A comparison of the duration of life from the time of diagnosis of Hodgkin's disease with, and without, hepatomegaly reveals no significant difference. The five- and 10-year survival in our series did not differ statistically from a series of 713 cases reported by Diamond (1958b) from the Memorial Center, in which survival was calculated from the first hospital visit rather than from the time of diagnosis of Hodgkin's disease. Although the interval from the first hospital visit to death is not identical with the interval from diagnosis to death, the difference was small generally and could not significantly influence 
the five- and 10-year survival time. Survival in Diamond's series was $19.5 \%$ at five years and $7.2 \%$ at 10 years in comparison with $19.6 \%$ and $4.5 \%$ respectively in this series.

It is noteworthy that, despite the fact that all the patients in our series had liver abnormalities, only three patients $(2.8 \%)$ died in hepatic coma, two as the result of intercurrent viral hepatitis and only one directly attributable to Hodgkin's disease of the liver.

Liver disease becomes suspect in the patient with Hodgkin's disease by the usual clinical (or radiological) criteria of liver enlargement, jaundice, ascites, peripheral oedema, or abnormal liver function tests. Among the liver function tests, the most useful, in order of frequency of abnormal findings, were bromosulphalein (BSP) retention, prothrombin time, total protein, serum albumin, alkaline phosphatase, cephalin flocculation, serum bilirubin, and thymol turbidity. However, since the incidence of specific abnormalities and clinical signs did not differ significantly in those patients with Hodgkin's disease of the liver from those with other forms of liver disease, these tests fail to distinguish the two groups, findings in agreement with those of other authors (Abbatucci and Beatty, 1953; Sherlock, 1955). Only those patients with massive hepatomegaly (below the pelvic brim) had uniform involvement with Hodgkin's disease, suggesting that this degree of hepatic enlargement is of clinical value in evaluating the state of the liver.

Liver biopsy was performed too infrequently $(2.8 \%)$ in the present series to permit evaluation of its importance. Haemorrhagic tendencies, a not uncommon manifestation of advanced Hodgkin's disease, particularly after various forms of therapy, prohibited the use of liver biopsy in many instances.

The difficulty in establishing a correct and precise clinical diagnosis of liver pathology in Hodgkin's disease is clearly due to the multiplicity of type of lesions that may be encountered at the same time within the liver and the biliary tree in any one case. The correct diagnosis, however, is not simply of academic interest, particularly in those instances in which choledocholithiasis, hepatitis, cirrhosis, or bacterial infections were present. Radiotherapy or chemotherapy, in such instances, may further complicate the problem. On the other hand, it is equally poor care to withhold specific therapy in the patient who is jaundiced because of tumorous lymph nodes obstructing the extrahepatic bile ducts, where radiotherapy may offer palliation of the very disturbing pruritus (Levitan et al., 1961). Furthermore, any evaluation of the efficacy of a method of therapy for Hodgkin's disease of the liver is obviously impossible without a correct diagnosis at the onset of therapy. Therefore, every effort should be made to establish, in detail, the cause of liver disease before the institution of therapy in the patient with Hodgkin's disease. A high index of suspicion of the possibility of unrelated liver disease in the patient with established diagnosis of Hodgkin's disease, combined with full utilization of liver function tests, liver biopsy (when feasible), intravenous cholangiography, and/or lienoportography (when feasible) may contribute to a more accurate antemortem diagnosis. Evaluation of new diagnostic tests, such as serum iron and serum $B_{12}$ determinations, and enzyme assays (Grossowicz, Hochman, Aronovitch, Izak, and Rachmilewitz, 1957), and radio-tracer scanning of the liver (Friedell, MacIntyre, and Rejali, 1957) may uncover important clues leading to improved diagnosis. Serial liver function tests or serial liver biopsies may contribute greatly to our understanding of the relationship between Hodgkin's disease and intercurrent liver disease as a dynamic process.

\section{SUMMARY}

Three hundred (34.3\%) of 875 patients with histologically proven Hodgkin's disease had clinical evidence of associated liver disease. One hundred and twelve cases of the $300(37 \%)$ were subject to necropsy and critical clinical and pathological study. In the necropsy series, $66 \%$ had direct involvement of the liver with Hodgkin's disease, and $34 \%$ exhibited other pathology in the liver.

Seventy-nine per cent of the patients with Hodgkin's disease of the liver also had other pathological changes in this organ, and $32.4 \%$ had biliary tract disease as well.

Diffuse involvement of the liver by Hodgkin's disease was the most common type of intrahepatic distribution $(86.5 \%)$, whereas discrete nodular lesions were found in only $10.8 \%$ and the combined diffuse and nodular type was encountered in only $2.7 \%$.

Hodgkin's granuloma was most frequently localized to the portal triads and was not seen invading the blood vessels.

Hodgkin's sarcoma tended to involve the liver in a more diffuse and extensive manner and frequently invaded the blood vessels.

The larger bile ducts were invaded or compressed by Hodgkin's granuloma or sarcoma in $21.8 \%$ of the cases with liver involvement.

In patients free of Hodgkin's disease in the liver itself but with histological evidence of Hodgkin's disease elsewhere, pathological changes of some kind were found in all livers. Some combination of 
chronic passive congestion, fatty metamorphosis, or haemosiderosis was encountered in $50 \%$ of such cases; biliary tree pathology due to Hodgkin's disease in $10.5 \%$; and unrelated biliary tree pathology in $6 \cdot 2 \%$. Statistical analysis of the incidence of hepatic changes indicated no significant correlation of these findings with the presence or absence of direct involvement of the liver by Hodgkin's disease.

Despite the almost uniform finding of liver pathology in patients with Hodgkin's disease in this series, only $2.8 \%$ of the patients died as a consequence of clinical liver failure, one attributable to Hodgkin's disease directly and two to intercurrent hepatitis.

The five- and 10-year survival rate in this series, selected on the basis of clinical evidence of hepatic disease, did not differ significantly from the survival rate of Hodgkin's disease in general as encountered at Memorial Hospital. The presence or absence of hepatomegaly, the degree of hepatomegaly, splenomegaly, and sex did not significantly influence survival.

At the present time, on the basis of clinical findings and currently available liver function tests, it is impossible to distinguish reliably between liver disease due to Hodgkin's disease itself and that due to associated hepatic changes. Perhaps the only reliable sign of direct involvement of the liver in the Hodgkin's process is the enlargement of the liver below the pelvic brim.

Statistical analysis of the sex distribution of involvement with Hodgkin's disease failed to confirm a previous report of predilection of males to hepatic Hodgkin's disease. By similar statistical criteria, however, splenic involvement with Hodgkin's disease was more frequent, in our series, than the anticipated incidence. The significance of this observation is obscure.

Clinical hepatomegaly was encountered in $79.5 \%$ of the necropsied series of patients with Hodgkin's disease selected on the basis of evidence of liver disease, and it was seen relatively early, in some instances, in the course of the Hodgkin's process.

It is concluded that hepatic involvement by Hodgkin's disease is but one manifestation of a generalized disease process, that it carries no prognostic significance for survival, that it may occur early or late, and that it is frequently associated with one or more abnormalities of liver structure which may be unrelated to Hodgkin's disease. With the single exception of massive hepatomegaly, no clinical sign establishes the presence of the Hodgkin's process within the liver itself, and liver biopsy, the only currently available test capable of the definitive diagnosis of hepatic Hodgkin's disease, is often interdicted by complicating factors.
We are grateful to Dr. Stephen S. Sternberg, of the Department of Pathology, Memorial Center for Cancer and Allied Diseases, for his review of the pathological material, and to Dr. Herbert A. Ravin, research assistant Beth-Israel Hospital, Boston, Mass., for his help in the preparation of this manuscript.

\section{REFERENCES}

Abbatucci, J. S., and Beatty, E. C. (1953). Atteinte hépatique dans la maladie de Hodgkin. Différences dans les deux sexes. Bull. Ass. franc. Cancer, 40, 371-382.

Ackerman, L. V., and del Regato, J. A. (1954). Cancer: Diagnosis, Treatment and Prognosis, 2nd ed. Mosby, St. Louis.

Ariel, I. M., and Shahon, D. B. (1950). Hepatic dysfunction in candidates for abdominal surgery, especially in patients with cancer. Cancer, 3, 608-623.

Baker, C., and Mann, W. N. (1939). Hodgkin's disease. A study of 65 cases. Guy's Hosp. Rep., 89, 83-107.

Barié, E. (1875). Lymphadénie sans leucémie; hypertrophie généralisée des ganglions lymphatiques tumeurs lymphoides du foie, de la rate, des reins, du coeur, de la peau, etc. Bull. Soc. anat. Paris, 50 (3 ser., 10), 711-719.

Barron, M. (1926). Two rare cases of Hodgkin's disease: (a) chronic relapsing fever of Pel-Ebstein type; (b) Hodgkin's disease with extensive cutaneous manifestations. Arch. Path. (Chicago), 2, 616 .

Beatty, E. C., Jr. (1954). Jaundice in Hodgkin's disease. Bull. N.Y. Acad. Med., 30, 409-412.

Bodansky, M., and Bodansky, O. (1952). Biochemistry of Disease, 2nd ed. Macmillan, New York.

Brauneck, H. (1889). Uber einen Fall von multipler Lymphombildung (Hodgkin'scher Krankheit), welcher unter hohem Fieber, Icterus und Nephritis zum Tode führte. Dtsch. Arch. klin. Med., 44, 297-310.

Brunner, A. (1925). Ein Fall von Lymphogranulomatose mit stürmischem Verlauf. Wien. klin. Wschr., 38, 930-932.

Burnam, C. F. (1926). Hodgkin's disease, with especial reference to its treatment by irradiation. J. Amer. med. Ass., 87, 1445-1452.

Chevallier, P., and Bernard, J. (1932). La maladie de Hodgkin. Masson, Paris.

Coronini, C. (1928). Uber das Paltauf-Sternberg'sche Lymphogranulom, mit besonderer Berücksichtigung der Veränderungen des Verdauungsschlauches und solcher an der Leberpforte mit und ohne Gelbsucht. Zugleich ein Beitrag über lymphogrnaulomatőse Gefăssverănderungen. Beitr. path. Anat., 80, $405-478$.

Craver, L. F. (1957). Hodgkin's Disease. In The Practice of Medicine Vol. 5 . Edited by L. Hendrick Sloan. Hagerstown, Md.

Diamond, H. D. (1958a). The Lymphomas. Disease-a-Month, pp. 38-60.

- (1958b). Results of therapy in Hodgkin's disease. Ann. N.Y. Acad. Sci., 73, 357-362.

- (1958c). The Medical Management of Cancer. Grune \& Stratton, New York.

Ewing, J. (1940). Neoplastic Diseases, 4th ed. Saunders, Philadelphia. Fabian, E. (1911). Die Lymphogranulomatosis (Paltauf-Sternberg). Zbl. allg. Path. path. Anat., 22, 145-186.

Foulon, P. (1932). A propos de quelques lésions extra-ganglionnaires de la lymphogranulomatose. Ann. Anat. path., 9, 725-744.

Fox, H. (1936). Remarks on microscopical preparations made from some of the original tissue described by Thomas Hodgkin, 1832. Guy's Hosp. Rep., 86, 11-16.

Friedell, H. L., MacIntyre, W. J., and Rejali, A. M. (1957). A method for the visulization of the configuration and structure of the liver. Part A. Preliminary clinical investigations. Amer. J. Roentgenol., 77, 455-470.

Gall, E. A. (1956). In Diseases of the Liver, ed. L. Schiff. Lippincott, Philadelphia.

- and Mallory, T. B. (1942). Malignant lymphoma. A clinico pathologic survey of 618 cases. Amer. J. Path., 18, 381-415.

Goia, I. (1935). Contributions à la forme hepatique de la lymphogranulomatose maligne. Sang., 9, 367-374.

Goldman, L. B. (1940). Hodgkin's disease; an analysis of 212 cases. J. Amer. med. Ass., 114, 1611-1616. 
Grossowicz, N., Hochman, A., Aronovitch, J., Izak, G., and Rachmilewitz, M. (1957). Malignant growth in the liver and serum-vitamin-B 12 levels. Lancet, 1, 1116-1117.

Gruber, G. B. (1930). Spezielle Infektionsfolgen der Leber. IX. Lymphogranulomatose. In Handbuch der speziellen pathologischen Anatomie und Histologie, ed. F. Henke and 0. Lubarsch, Vol. 5, Pt. I, pp. 604-615. Springer, Berlin.

Hartfall, S. J. (1932). Hodgkin's disease of the lung. Guy's Hosp. Rep., 82, $55-74$.

Hill, A. B. (1955). Principles of Medical Statistics, 6th ed. The Lancet, London.

Hodgkin, T. (1832). On some morbid appearances of the absorbent glands and spleen. Med.-chir. Trans., 17, 68-114. London. Reprinted in Med. Classics, 1, $741-770$ (1937).

Hoster, H. A., Zanes, R. P., Jr., and Haam, E. von (1949). The association of 'viral' hepatitis and Hodgkin's disease (a preliminary report). Cancer Res., 9, 473-480.

-, Dratman, M. B., Craver, L. F., and Rolnick, H. A. (1948). Hodgkin's disease (1832-1947). Ibid, 8, 1-78.

Jackson, H., and Parker, F. (1947). Hodgkin's Disease and Allied Disorders. Oxford Univ. Press, New York.

Klein, F. (1955). Uber einen Fall von akut verlaufender Lymphogranulomatose. Zbl. allg. Path. path. Anat., 93, 19-27.

Levitan, R., Diamond, H. D., and Craver, L. F. (1959). Esophageal varices in Hodgkin's disease involving the liver. Amer. J. Med., 27, 137-143.

$-\frac{1}{111},-(1961)$. Jaundice in Hodgkin's disease. Ibid, 30, 99. 111.

Lichtman, S. S. (1953). Diseases of the Liver, Gallbladder and Bile Ducts, 3rd ed. Vol. 2. Lea \& Febiger, Philadelphia.

Loeper, M., and Lebret, G. (1940). Association de tubercules et l'infiltration granulomateuse dans le foie d'une maladie de Hodgkin terminee par ictère. Bull. Soc. méd. Hop. Paris, 3 ser., 56, 492-498.

Longcope, W. T. (1903). On the pathological histology of Hodgkin's disease, with a report of a series of cases. Bull. Ayer clin. Lab., 1, 4-76.

- , and McAlpin, K. R. (1927). In A Textbook of Medicine by American Authors. Saunders, Philadelphia.

Mendelsohn, M. L., and Bodansky, O. (1952). The value of liverfunction tests in the diagnosis of intrahepatic metastases in the nonicteric cancer patient. Cancer, 5, 1-8.

Muller, G. P., and Boles, R. S. (1927). Abdominal manifestations of Hodgkin's disease. J. Amer. med. Ass., 88, 301-307.

Murchison, C. (1869). "Lymphatic new formations" in the liver, with enlargement of the spleen and persistent jaundice, in a child aged 12. Trans. path. Soc. Lond., 20, 198-203.

Murray, G. R. (1908). Lymphadenoma. In A System of Medicine, ed. C. Allbutt and H. D. Rolleston, Vol. 4, Pt. I, pp. 459-481. Macmillan, London. Cited in Fabian, E. (1911).

Newman, B., and Pushkin, W. (1951). Acute fulminating Hodgkin's disease. J. Amer. med. Ass., 146, 335-337.

Pène, P. (1952). Foie et lymphogranulomatose de Hodgkin. Gaz. méd. Fr., 59, 1245-1250.
Pène, P., Paquier, P. du, Alium, and Pène, J. A. (1955). Forme hépatosplénomégalique prédominante de la maladie de Hodgkin. Bordeaux chir., 2, 93-94.

Popper, H., and Schaffner, F. (1957). Liver: Structure and Function. McGraw-Hill, New York.

Reed, D. M. (1902). On the pathological changes in Hodgkin's disease, with especial reference to its relation to tuberculosis. Johns Hopk. Hosp. Rep., 10, 133-196.

Robert, Bréchot, and Ruynat (1957). A propos d'une forme hépatique de la maladie de Hodgkin. Arch. Mal. Appar. dig., 46, 822-828.

Rolleston, H. D. (1912). Diseases of the Liver, Gallbladder and BileDucts, 2nd ed. Macmillan, London.

Ross, R. S., Iber, F. L., and Harvey, A. McG. (1956). The serum alkaline phosphatase in chronic infiltrative disease of the liver. Amer. J. Med., 21, 850-856.

Schiff, L. (1957). Absence of a palpable liver - a sign of value in excluding obstructive jaundice due to pancreatic cancer. Gastroenterology, 32, 1143-1144.

Schmorl (1922). Case presentation before the Gesellschaft für Natur und Heilkunde zu Dresden, on 20 March 1922. Münch. med. Wschr., 69, 908.

Sherlock, S. (1955). Diseases of the Liver and Biliary System. Blackwell, Oxford.

Simonds, J. P. (1926). Hodgkin's disease. Arch. Path. (Chicago), 1, 394-430.

Sternberg, C. (1936). Lymphogranulomatose und Reticuloendotheliose. Ergebn. allg. Path. path. Anat., 30, 1-76.

Symmers, D. (1944). Clinical significance of the deeper anatomic changes in lymphoid diseases. Arch. intern. Med., 74, 163-171.

Terplan, K., and Mittelbach, M. (1929). Beiträge zur Lymphogranulomatose und $\mathrm{zu}$ anderen eigenartigen, verallgemeinerten Granulomen der Lymphknoten. Virchows Arch. path. Anat. 271, 759-866.

Tschekulajev, G. N. (1951). The cytodiagnosis of lymphogranulomatosis in effusions. Klin. Med. (Mosk.), 29, No. 4, pp. 60-63.

Uddströmer, M. (1934). On the occurrence of lymphogranulomatosis (Sternberg) in Sweden 1915-1931 and some considerations as to its relation to tuberculosis. Acta tuberc. scand., Suppl. 1, pp. 1-225.

U.S. Dept. of Health, Education and Welfare (1958). Vital Statistics special reports. Mortality from each cause by color and sex, U.S. 1956, Publ. Hith Serv., 48, 5.

Wallhauser, A. (1933). Hodgkin's disease-general review. Arch. Path. (Chicago), 16, 522-562 and 672-712.

Wilks, S. (1865). Cases of enlargement of the lymphatic glands and spleen (or, Hodgkin's disease), with remarks. Guy's Hosp. Rep., 3 ser., 11, 56.

Woldman, E. E., Fishman, D., and Segal, A. J. (1959). Relation of fibrosis of the pancreas to fatty liver and/or cirrhosis. An analysis of one thousand consecutive autopsies. J. Amer. med. Ass., 169, 1281-1283.

Wróblewski, F., and LaDue, J. S. (1955). Serum glutamic-oxalacetictransaminase activity as an index of liver-cell injury from cancer. Cancer, 8, 1155-1163.

Ziegler, K. (1911). Die Hodgkinsche Krankheit. Fischer, Jena. 